\title{
OVIPOSITION PREFERENCE AND BIOLOGY OF FRUIT FLIES (DIPTERA: TEPHRITIDAE) ON GRAPE VINE GENOTYPES ${ }^{1}$
}

\author{
SABRINA CRISTINA CORREA ${ }^{2}$, CLEITON LUIZ WILLE², HADSON HOFFER ${ }^{2}$, MARI INÊS CARISSIMI BOFF², \\ CLÁUDIO ROBERTO FRANCO ${ }^{2 *}$
}

\begin{abstract}
Grape orchards are highly affected by oviposition of fruit flies on grape berries, which compromises the productivity and quality of the grapes. The goal of this study was to evaluate the susceptibility of American, European, and hybrid grape genotypes to Anastrepha fraterculus and Ceratitis capitata (Diptera: Tephritidae) under laboratory conditions $\left(25 \pm 2^{\circ} \mathrm{C}, 60 \pm 10 \% \mathrm{RH}\right.$, and 14-hour photophase). The assays were conducted by evaluating oviposition preference through choice and no-choice (antibiosis) tests. The choice test was set up using circular arenas (diameter: $300 \mathrm{~mm}$ ) with 10 grapes per genotype. The no-choice test was set up using 150 grapes per genotype which were placed inside plastic boxes (417 x 297 x 289 mm). After exposure of the grapes to one or two couples of fruit flies per genotype in choice and no-choice tests, respectively, the grapes were transferred to transparent plastic containers $(750 \mathrm{~mL})$. The number of eggs per grape and its viability were evaluated. The no-choice test also evaluated the biological cycle of the fruit flies. The assays were conducted in a completely randomized design with 15 replicates. The most preferred grapes for oviposition by A. fraterculus were Cabernet Sauvignon, Niagara Rosada, and BRS Cora, while C. capitata mainly preferred Isabel Precoce grapes. We observed the complete development of fruit flies in the Moscato Embrapa grapes, but this only occurred with $C$. capitata. All genotypes evaluated were considered susceptible to $A$. fraterculus and C. capitata. However, the fruit flies expressed differences in preference for oviposition and host quality.
\end{abstract}

Keywords: Vitis spp.. Tephritidae. Biology. Resistance of plants.

\section{PREFERÊNCIA PARA OVIPOSIÇÃO E BIOLOGIA DE MOSCAS-DAS-FRUTAS (DIPTERA: TEPHRITIDAE) EM GENÓTIPOS DE VIDEIRA}

\begin{abstract}
RESUMO - No cultivo da videira a oviposição das moscas-das-frutas compromete a produtividade e a qualidade de bagas de uva. O objetivo desse trabalho foi avaliar a suscetibilidade de genótipos de uvas americanas, europeias e híbridas à Anastrepha fraterculus e Ceratitis capitata (Diptera: Tephritidae) em laboratório $\left(25 \pm 2^{\circ} \mathrm{C}, 60 \pm 10 \%\right.$ UR e fotofase de 14 horas) por meio de ensaios de preferência de oviposição com e sem chance de escolha (antibiose). No ensaio com chance de escolha foram utilizadas arenas circulares (300 mm de diâmetro) com 10 bagas por genótipo de uva. No teste sem chance de escolha foram utilizadas 150 bagas por genótipo de uva acondicionadas em caixa plástica (417 x 297 x 289 mm). Após a exposição a um ou a dois casais de moscas-das-frutas, por genótipo de uva nos testes com e sem chance de escolha, respectivamente, as bagas foram transferidas para potes plásticos transparentes $(750 \mathrm{~mL})$. Nos ensaios foram avaliados o número de ovos por baga e sua viabilidade. No ensaio sem chance de escolha também foi avaliado o ciclo biológico das moscas-das-frutas (teste de antibiose). Os experimentos foram conduzidos em delineamento inteiramente casualizado com 15 repetições. As bagas de uvas preferidas para oviposição por $A$. fraterculus foram Cabernet Sauvignon, Niágara Rosada e BRS Cora. Para C. capitata foi a Isabel Precoce. No genótipo Moscato Embrapa foi observado o desenvolvimento de ovo-adulto apenas de C. capitata. Assim, todos os genótipos foram considerados suscetíveis à $A$. fraterculus e $C$. capitata. No entanto, expressam diferenças na preferência para oviposição e na qualidade hospedeira para A. fraterculus e C. capitata.
\end{abstract}

Palavras-chave: Vitis spp.. Tephritidae. Biologia. Resistência de plantas.

\footnotetext{
*Corresponding author

${ }^{1}$ Received for publication in $05 / 04 / 2017$; accepted in $03 / 20 / 2018$

Paper extracted from the master dissertation of the first author.

${ }^{2}$ Department of Agronomy, College of Agriculture and Veterinary, Universidade do Estado de Santa Catarina, Lages, SC, Brazil; sabri_cristina@hotmail.com - ORCID: 0000-0003-4247-1559, cleitonwille@gmail.com - ORCID: 0000-0002-0097-7394, hadson.hoffer@gmailcom - ORCID: 0000-0002-4060-1930, mari.boff@udesc.br - ORCID: 0000-0003-1700-8837,
} claudio.franco@udesc.br - ORCID: 0000-0001-7944-0671. 


\section{INTRODUCTION}

Temperate fruit crops account for about $7.5 \%$ of fruit production in Brazil, and of these, grapes and apples play a very important role, as they account for around $80-85 \%$ of this production (FACHINELLO et al., 2011). The southern and northeastern regions of Brazil are the main areas for the production of grapes, and they accounted for $53 \%$ and $41 \%$ of the Brazilian production, respectively, in 2016 (MELLO, 2017). In the southern region, genotypes of American grapes (Vitis labrusca L.) and interspecific hybrids are dominant, and represent up to $80 \%$ of the grape vines, with the remainder made up of genotypes belonging to the European species (Vitis vinifera L.) (PROTAS; CAMARGO, 2011).

Fruit fly infestations in grape vines are characterized by the presence of galleries in fruits, deformations, and premature fruit drop, which are caused by the larvae (ZART; BOTTON; FERNANDES, 2011). In addition to the direct damage, the presence of punctures after oviposition by flies can contribute to the establishment of pathogenic microorganisms that cause berries to rot (MACHOTA JÚNIOR et al., 2013; 2016).

The South American fruit fly, Anastrepha fraterculus (Wied.) (Diptera: Tephritidae), is the species of greatest abundance and economic importance in the south of Brazil (GARCIA, NORRBOM, 2011). However, in the southern state of Rio Grande do Sul, another fruit fly, known as the Mediterranean fruit fly, Ceratitis capitata (Wied.) (Diptera: Tephritidae), occurs at lower densities (GARCIA; CORSEUIL, 1998; GARCIA, NORRBOM, 2011). High densities of C. capitata were detected near the city of Pelotas-RS in several fruit trees, representing up to $30 \%$ of the tephritid entomofauna (NAVA et al., 2008).

Winemakers adopt the use of insecticides in order to reduce the infestation of fruit flies in grape vines (FORMOLO et al., 2011). However, due to the global restrictions on their use, one of the alternatives for the management of these insect pests is the use of plants that have defense mechanisms against herbivory. These plant defense mechanisms can be of three types, known as non-preference (antixenosis), antibiosis, and tolerance (MUHAMMAD et al., 2010).

Grape genotypes show differences in susceptibility to infestation with different fruit fly species. The development of $A$. fraterculus from egg to adult was observed in Moscato Embrapa and Itália grape genotypes (ZART; FERNANDES; BOTTON, 2010; ZART; BOTTON; FERNANDES, 2011). The development of $C$. capitata was observed in the genotypes Itália, Benitaka, and Festival (GÓMEZ et al., 2008; ZANARDI et al., 2011).

It is crucial to know the susceptibility of grape genotypes to these insect pests, in order to estimate the potential damage that may be caused to grapes by fruit flies, and to assess the importance of the grape vine as a host plant. Through this process, fruit fly management strategies can be incorporated. Therefore, the present study evaluated the susceptibility of grape genotypes to $A$. fraterculus and $C$. capitata by means of non-preference to oviposition and antibiosis assays under laboratory conditions.

\section{MATERIAL AND METHODS}

Grape genotypes

The assays were conducted from October 2013 to February 2014. Grape vines used in the assay were from an espalier system, where plants were spaced $0.5 \mathrm{~m}$ apart each other, and there was a space of $1.0 \mathrm{~m}$ between rows. In order to avoid natural infestation by fruit flies, the grapes were bagged with polypropylene fabric bags (ZART; BOTTON; FERNANDES, 2011). The grape berries were harvested at either the phenological stage of full maturation, or when the total soluble solids content was $14^{\circ} \mathrm{Bx}$.

The genotypes Cabernet Sauvignon, Sauvignon Blanc $(V$. vinifera), Niagara Rosada, BRS Linda, BRS Lorena, BRS Cora, Moscato Embrapa, and Maselair (Hybrids) were used for the assays with A. fraterculus. For the antibiosis test, the Sauvignon Blanc genotype was not used due to the low availability of grapes in that year. For the assays with $C$. capitata, the Isabel Precoce ( $V$. labrusca), BRS Lorena, BRS Cora, Moscato Embrapa and Maselair genotypes were used. The same grape genotypes were not used for both species of fruit flies due to a lack of available grapes.

Fruit fly rearing

The adults of $A$. fraterculus were obtained from the laboratory, where they were reared in semitransparent plastic cage $(417 \times 297 \times 289 \mathrm{~mm})$ with the top and the sides covered by voile fabric. Papaya fruits were provided to the flies as oviposition substrate (MACHOTA JÚNIOR et al., 2010). The diet of adults was composed of a solid diet with wheat germ, beer yeast (Bionis $(\AA$ YE MF), and refined sugar at a ratio of 1:1:3 (MORELLI et al., 2012).

Adults of $C$. capitata were reared with the same procedures as described above. However, the eggs were removed from the side wall of the cages and inoculated into a $200 \mathrm{~mm}$ diameter petri dish containing a carrot base substrate as proposed by Teran (1977). The rearing was done under laboratory conditions in $25 \pm 2^{\circ} \mathrm{C}, 60 \pm 10 \% \mathrm{RH}$ and 14-hour photophase. 
Choice test

For the choice tests, circular arenas, $300 \mathrm{~mm}$ in diameter and $125 \mathrm{~mm}$ in height $(\mathrm{n}=15$ replicates $)$, were used. The cover of these arenas was made of voile fabric and contained a hole in the form of a sleeve. Petri dishes $(100 \mathrm{~mm})$ containing 10 grapes were distributed equidistantly inside of each arena. An adult couple of $A$. fraterculus, 15 to 25 days old, or C. capitata, 8 to 10 days old, were released inside of the cages with the aid of an insect aspirator. Each cage included one grape genotype and one fruit fly species. During the assays, two $20 \mathrm{~mm}$ diameter acrylic plates with solid diet and two with a hydrophilic cotton ball soaked in distilled water were placed inside these arenas. The assays were conducted under laboratory conditions in $25 \pm 2^{\circ} \mathrm{C}$, $60 \pm 10 \% \mathrm{RH}$ and 14-hour photophase.

No-choice test

No-choice tests were done using $750 \mathrm{~mL}$ transparent plastic containers $(n=15$ replicates $)$. We placed two modified Pasteur type pipettes on the lateral side of these containers. These pipettes contained a solid diet and a cotton ball soaked in distilled water. In the interior of these containers, we placed a $100 \mathrm{~mm}$ petri dish with ten grape berries. Two adult couples of $A$. fraterculus, 15 to 25 days old or $C$. capitata, 8 to 10 days old, were then released inside of the cages.

After 24 hours of the berries being exposed to the fruit flies, the peel of the grapes was removed with the aid of a stylet, in order to assess the number of eggs oviposited. To evaluate the viability of the eggs, two grapes from each replicate of the nochoice test were transferred to $250 \mathrm{~mL}$ plastic containers containing sterilized superfine vermiculite (ZART; FERNANDES; BOTTON, 2010). The presence of larvae or hatched eggs was evaluated in these grapes after four days.

The antibiosis test was done by placing 150 grapes of each genotype in separate plastic cages with either 15 adult couples of $A$. fraterculus, 15 to 25 days old, or 45 couples of $C$. capitata, 8 to 10 days old. After six hours of exposure of the fruits to the fruit flies, the grape berries were removed from the plastic cage to avoid an excess of eggs per grape, which could reduce the availability of food for the larvae. Soon after, the grape berries were randomly distributed in 15 plastic containers $(750 \mathrm{~mL})$ containing sterilized superfine vermiculite.

The development of fruit fly species in grape genotypes was observed daily. The period from egg to larva was obtained using the day of the infestation until the first pupa was detected. The pupal period was estimated using the obtained pupae, which were transferred to $145 \mathrm{~mL}$ plastic containers with sterilized superfine vermiculite, and observed when adult emergence happened. The viability of pupae was determined by the ratio between the number of emerged adults and the number of pupae obtained. Sex ratio (sr) was also calculated using the equation $[\mathrm{sr}=$ females counted/ (females counted + males counted)].

The adults were separated into couples with a maximum difference of one day apart and placed in $750 \mathrm{~mL}$ plastic containers with two modified Pasteur pipettes ( $\mathrm{n}=15$ replicates). A solid diet and a cotton ball soaked in distilled water were supplied during the assays. Daily evaluations were performed to determine the periods of pre-oviposition, oviposition, post-oviposition, female and male longevity, and number of eggs per female. In order to evaluate the number of eggs per female, artificial grapes were prepared using an agar substrate $(3.0 \mathrm{~g})$, distilled water $(85 \mathrm{~mL})$, artificial red dye $(250 \mu \mathrm{L})$ and artificial grape aroma $(200 \mathrm{~mL})$ which were then coated with parafilm $M \circledR$ (SALLES, 1992). The data collected was also used to calculate survival rate (lx), survival of adults at a specific $\mathrm{x}$ and $\mathrm{mx}$ age, and the number of offspring generated by a female that will originate females at a specific age $\mathrm{x}$ (SILVEIRA NETO et al., 1976).

Physical-chemical analyses of the grape genotypes

Physical-chemical analyses were performed using 150 grapes of each genotype. The longitudinal diameter of the berries was measured using a digital caliper. The content of total soluble solids (SS) in the berries, expressed as degrees Brix, was obtained by using a digital refractometer. The $\mathrm{pH}$ of the berries was obtained using a digital potentiometer (RIBEREAU-GAYON et al., 1998)

\section{Statistical analysis}

The experimental design used was completely randomized. The number of eggs obtained in the choice and no-choice tests were transformed into $\sqrt[2]{x+1}$, and the egg viability percentage in arcsin $\sqrt[2]{x / 100}$. The data were analyzed using analysis of variance. The means were compared using the Duncan test, and the survival rate (lx) was compared with the Log-Rank test, with a significance level of $5 \%$. The data were analyzed using SAS statistical software, version 9.0 (SAS INSTITUTE, 2002).

\section{RESULTS AND DISCUSSION}

The first assay indicated that the most preferred grape genotypes for oviposition for $A$. fraterculus were Niagara Rosada and Cabernet Sauvignon, and these were preferred to the 
genotypes Maselair and BRS Linda $\left(\mathrm{F}_{3,56}=9.05, P=\right.$ 0.0001). The no-choice oviposition assay, which simulates a monoculture situation, demonstrated a significant difference in which the most preferred genotypes were Niagara Rosada, Cabernet Sauvignon and BRS Linda $\left(\mathrm{F}_{3,56}=5.05, P=0.0031\right)$ (Table 1).

The second assay performed (the choice test) indicated that the most preferred grape genotype was BRS Cora, while there was no difference in preference between the BRS Lorena, Moscato Embrapa, and Sauvignon Blanc genotypes $\left(\mathrm{F}_{4,70}=\right.$ $11.86, P=0.0001)$. The no-choice assay emphasized that BRS Lorena and Sauvignon Blanc genotypes were the most and least preferred genotypes for oviposition, respectively (Table 1).

The females of $C$. capitata showed greater preference for ovipositing in the grapes of the Isabel Precoce genotype $\left(\mathrm{F}_{4,70}=8.25, P=0.0001\right)$. The nochoice test indicated that the Isabel Precoce, Moscato Embrapa and BRS Lorena genotypes were more susceptible to oviposition, and they did not differ from each other $\left(\mathrm{F}_{4,70}=3.18, P=0.0184\right)$. The Maselair and BRS Cora genotypes had the lowest number of eggs, but this was not significantly different from the BRS Lorena genotype (Table 1).

Table 1. Mean number of eggs ( \pm standard error) of the South American fruit fly Anastrepha fraterculus (Wied.) and the Mediterranean fruit fly Ceratitis capitata (Wied.) (Diptera: Tephritidae) by grape genotypes in a choice and no-choice assay for oviposition under laboratory conditions $\left(25 \pm 2{ }^{\circ} \mathrm{C}, 60 \pm 10 \% \mathrm{RH}\right.$ and 14-hour photophase).

\begin{tabular}{|c|c|c|c|c|}
\hline $\begin{array}{l}\text { Fruit fly } \\
\text { species }\end{array}$ & Assay date & Grape genotypes & Choice & No-choice \\
\hline \multirow[t]{14}{*}{ A. fraterculus } & \multirow[t]{7}{*}{ 2014-02-06 } & Niagara Rosada & $4.30 \pm 0.77 \mathrm{a}$ & $6.69 \pm 0.65 \mathrm{a}$ \\
\hline & & Cabernet Sauvignon & $3.02 \pm 0.77 \mathrm{a}$ & $7.09 \pm 0.9 \mathrm{a}$ \\
\hline & & Maselair & $1.28 \pm 0.30 \mathrm{~b}$ & $3.80 \pm 0.65 b$ \\
\hline & & BRS Linda & $0.61 \pm 0.20 \mathrm{~b}$ & $5.32 \pm 0.57 \mathrm{a}$ \\
\hline & & F-value & 9.05 & 5.20 \\
\hline & & Degree of freedom & 3,56 & 3,56 \\
\hline & & Probability & $<0.0001$ & 0.0031 \\
\hline & \multirow[t]{7}{*}{ 2014-02-13 } & BRS Cora & $1.61 \pm 0.36 \mathrm{a}$ & $2.20 \pm 0.32 b$ \\
\hline & & BRS Lorena & $1.27 \pm 0.15 b$ & $3.86 \pm 0.62 \mathrm{a}$ \\
\hline & & Moscato Embrapa & $1.23 \pm 0.10 \mathrm{~b}$ & $2.09 \pm 0.28 b$ \\
\hline & & Sauvignon Blanc & $1.08 \pm 0.48 b$ & $0.32 \pm 0.11 \mathrm{c}$ \\
\hline & & F-value & 11.86 & 17.49 \\
\hline & & Degree of freedom & 3,56 & 3,56 \\
\hline & & Probability & $<0.0001$ & $<0.0001$ \\
\hline \multirow[t]{8}{*}{ C. capitata } & \multirow[t]{8}{*}{ 2014-02-17 } & Isabel precoce & $2.36 \pm 0.40 \mathrm{a}$ & $1.02 \pm 0.37 \mathrm{a}$ \\
\hline & & Moscato Embrapa & $1.16 \pm 0.31 \mathrm{~b}$ & $0.92 \pm 0.14 \mathrm{a}$ \\
\hline & & BRS Lorena & $0.73 \pm 0.19 b$ & $0.44 \pm 0.26 \mathrm{ab}$ \\
\hline & & BRS Cora & $0.62 \pm 0.19 b$ & $0.28 \pm 0.11 b$ \\
\hline & & Maselair & $0.38 \pm 0.11 b$ & $0.24 \pm 0.10 \mathrm{~b}$ \\
\hline & & F-value & 8.25 & 3.18 \\
\hline & & Degree of freedom & 4,70 & 4,70 \\
\hline & & Probability & $<0.0001$ & 0.0184 \\
\hline
\end{tabular}

Means followed by the same letters in the column do not differ from each other by Duncan's test at 5\% probability. 
Several factors can influence the oviposition behavior of fruit flies under natural or artificial host conditions, including host quality, color, maturation, size, firmness of the fruit, and the incidence of pheromone marking (DÍAZ-FLEISCHER; ALUJA, 2003). The most preferred genotypes for $A$. fraterculus oviposition were those of blue or crimson coloration, such as Niagara Rosada (crimson), Cabernet Sauvignon (blue), and BRS Cora (blue). The most preferred genotype for $C$. capitata oviposition was the Isabel Precoce genotype, which has blue grape berries.

The two choice tests performed with $A$. fraterculus indicated that the highest number of eggs were observed in Niagara Rosada and BRS Cora grapes, which had grapes with the largest diameter (Tables 1 and 2). This may indicate a searching behavior for larger hosts, due to the possibility of greater availability of food. However, the Cabernet Sauvignon genotype had grapes with one of the smallest diameters, and it did not differ from the Niagara Rosada genotype in the number of eggs per grape.

This behavior was also observed when soluble solids content was evaluated. The genotypes Niagara Rosada and BRS Cora had intermediate values of 16.3 and $18.4{ }^{\circ} \mathrm{Bx}$, while Cabernet Sauvignon had the lowest value of soluble solids $\left(12.5^{\circ} \mathrm{Bx}\right)$. The Sauvignon Blanc genotype had the lowest number of eggs per berry, and the highest soluble solids value $\left(21^{\circ} \mathrm{Bx}\right)$ (Table 1 and 2$)$.

C. capitata displayed the same behavior as $A$. fraterculus. Larger diameter grape genotypes, such as Isabel Precoce, had the highest number of eggs. However, there was a low preference for oviposition even in berries of larger diameter genotypes, such as BRS Lorena and BRS Cora (Table 2). For the soluble solids parameter, the Isabel Precoce genotype had the lowest value of degrees Brix (14.0 $\left.{ }^{\circ} \mathrm{Bx}\right)$.

The results indicate the possibility that an interaction among physical-chemical factors affects how fruit flies choose oviposition sites. This interaction can be different between fruit fly species, and may be dependent on the host plant. A study on pear fruits of the Packhams and Williams genotypes showed that the complete development of $A$. fraterculus occurred only in fruits which were 54.9 and $63.5 \mathrm{~mm}$ in diameter, respectively, and which had higher soluble solids content (NUNES et al., 2015). The increase in soluble solids content in kiwi fruits was also indicated as an important factor associated with the development of $A$. fraterculus under laboratory conditions (LORSCHEITER et al., 2012).

Table 2. Means ( \pm standard error) of physical-chemical parameters of grape genotypes.

\begin{tabular}{lllll}
\hline Assay date & Grape genotypes & Soluble solids $\left({ }^{\circ} \mathrm{Bx}\right)$ & $\mathrm{pH}$ & $\begin{array}{l}\text { Longitudinal } \\
\text { diameter }(\mathrm{cm})\end{array}$ \\
\hline 2014-02-06 & Niagara Rosada & $16.3 \pm 0.32 \mathrm{~b}$ & $3.5 \pm 0.01 \mathrm{a}$ & $1.8 \pm 0.01 \mathrm{a}$ \\
& Cabernet Sauvignon & $12.5 \pm 0.37 \mathrm{c}$ & $3.0 \pm 0.01 \mathrm{c}$ & $1.2 \pm 0.01 \mathrm{c}$ \\
& Maselair & $15.7 \pm 0.32 \mathrm{~b}$ & $2.9 \pm 0.02 \mathrm{~d}$ & $1.2 \pm 0.01 \mathrm{bc}$ \\
& BRS Linda & $19.0 \pm 0.51 \mathrm{a}$ & $3.3 \pm 0.02 \mathrm{~b}$ & $1.2 \pm 0.01 \mathrm{c}$ \\
& F-value & 45.68 & 308.89 & 557.41 \\
& Degree of freedom & 3,80 & 3,80 & 3,50 \\
& Probability & $<0.0001$ & $<0.0001$ & $<0.0001$ \\
& BRS Cora & & & $1.5 \pm 0.03 \mathrm{a}$ \\
& BRS Lorena & $18.4 \pm 0.75 \mathrm{~b}$ & $3.3 \pm 0.02 \mathrm{~b}$ & $1.3 \pm 0.02 \mathrm{~b}$ \\
& Moscato Embrapa & $18.9 \pm 0.58 \mathrm{ab}$ & $3.2 \pm 0.003 \mathrm{~b}$ & $1.2 \pm 0.02 \mathrm{~b}$ \\
& Sauvignon Blanc & $21.0 \pm 1.00 \mathrm{~b}$ & $3.4 \pm 0.03 \mathrm{a}$ & $1.2 \pm 0.02 \mathrm{~b}$ \\
& F-value & 5.30 & $3.3 \pm 0.02 \mathrm{~b}$ & 27.71 \\
& Degree of freedom & 3,80 & 6.82 & 3,50 \\
& Probability & 0.0264 & 3,80 & $<0.0001$ \\
& & 0.0135 & $1.6 \pm 0.03 \mathrm{a}$ \\
& Isabel precoce & $14.0 \pm 0.00 \mathrm{~b}$ & $3.3 \pm 0.01 \mathrm{ab}$ & $1.2 \pm 0.02 \mathrm{bc}$ \\
& Moscato Embrapa & $17.0 \pm 1.00 \mathrm{a}$ & $3.40 \pm 0.03 \mathrm{a}$ & $1.3 \pm 0.02 \mathrm{a}$ \\
& BRS Lorena & $18.9 \pm 0.58 \mathrm{a}$ & $3.2 \pm 0.00 \mathrm{~b}$ & $1.6 \pm 0.03 \mathrm{a}$ \\
& BRS Cora & $18.4 \pm 0.75 \mathrm{a}$ & $3.3 \pm 0.02 \mathrm{ab}$ & $1.1 \pm 0.01 \mathrm{c}$ \\
& Maselair & $17.6 \pm 0.23 \mathrm{a}$ & $3.1 \pm 0.07 \mathrm{c}$ & 47.73 \\
& F-value & 9.29 & 7.79 & 4,70 \\
Degree of freedom & 4,10 & 4,10 & $<0.0001$ \\
\hline
\end{tabular}

Means followed by the same letters in the column do not differ from each other by Duncan's test at $5 \%$ probability.

There was no significant difference in viability of $A$. fraterculus eggs oviposited in grapes of the BRS Linda, Niagara Rosada, Cabernet Sauvignon, and Maselair (66\% to 44\%) genotypes $\left(\mathrm{F}_{3,55}=2.65, P=0.0581\right)$ (Figure 1A). The second assay indicated that BRS Lorena and BRS Cora genotypes had the highest percentages of egg viability ( $94 \%$ and $92 \%$, respectively), and they did not differ from the Moscato Embrapa genotype, which had an intermediate egg viability value (64\%). Egg viability did not differ between the Moscato Embrapa and Sauvignon Blanc genotypes, which both had an egg viability of approximately $50 \%\left(\mathrm{~F}_{3}\right.$, $\left.{ }_{37}=4.74, P=0.0068\right)$ (Figure 1B). 


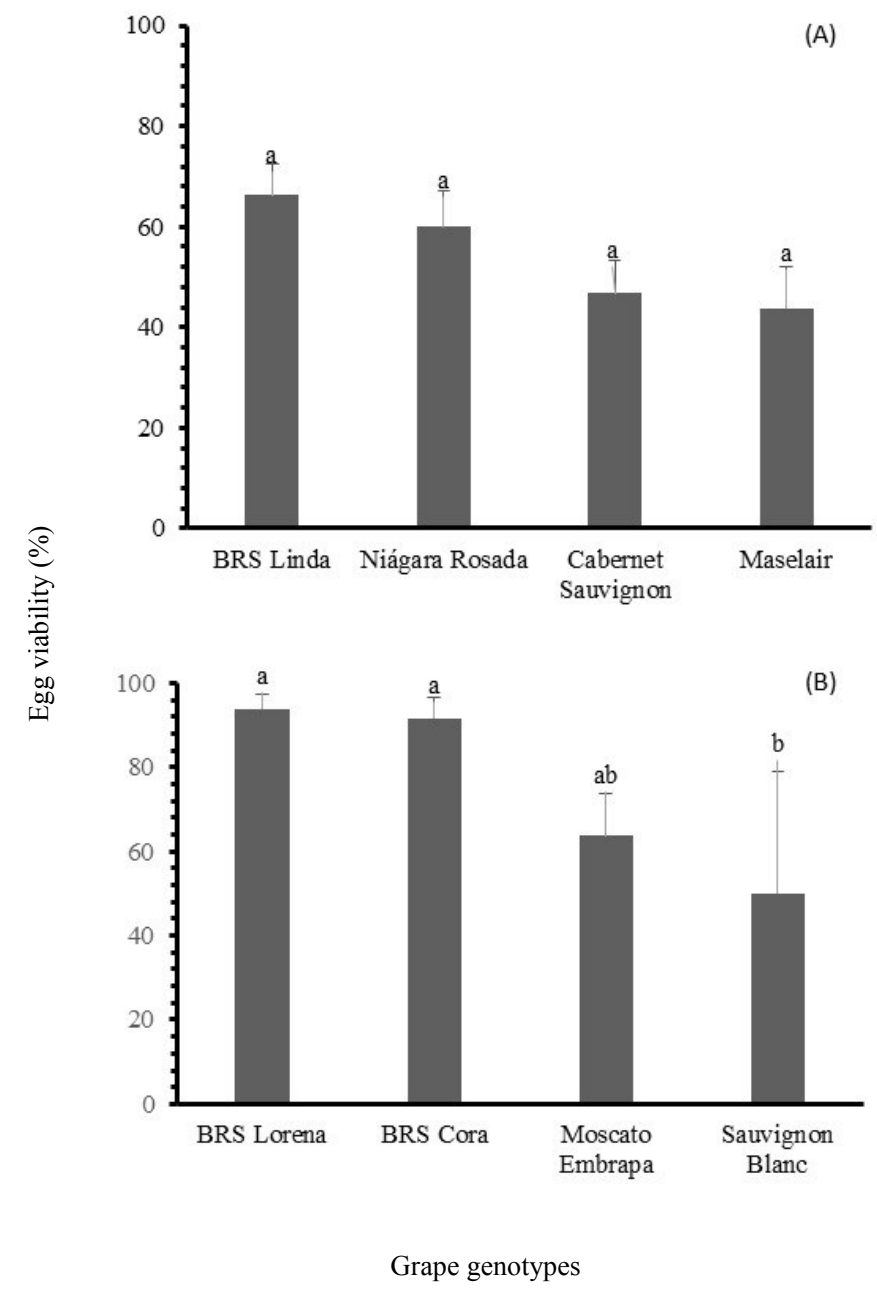

Figure 1. Viability of Anastrepha fraterculus eggs (Wied.) (Diptera: Tephritidae) in grape genotypes under laboratory conditions $\left(25 \pm 2^{\circ} \mathrm{C}\right.$, RH of $60 \pm 10 \%$ and 14-hour photophase). Grape berries were infested on (A) 2014-02-06 and (B) 2014-02-13. Means followed by the same letter do not differ by Duncan's test at 5\% probability.

The assay with $C$. capitata demonstrated that Maselair and BRS Cora genotypes had very distinct values of egg viability percentages, which were 100 and $19 \%$ respectively. BRS Lorena,
Moscato Embrapa, and Isabel Precoce genotypes had intermediate egg viability values $(80$ to $31 \%)\left(\mathrm{F}_{4,27}\right.$ $=5.40, P=0.0025)$ (Figure 2).

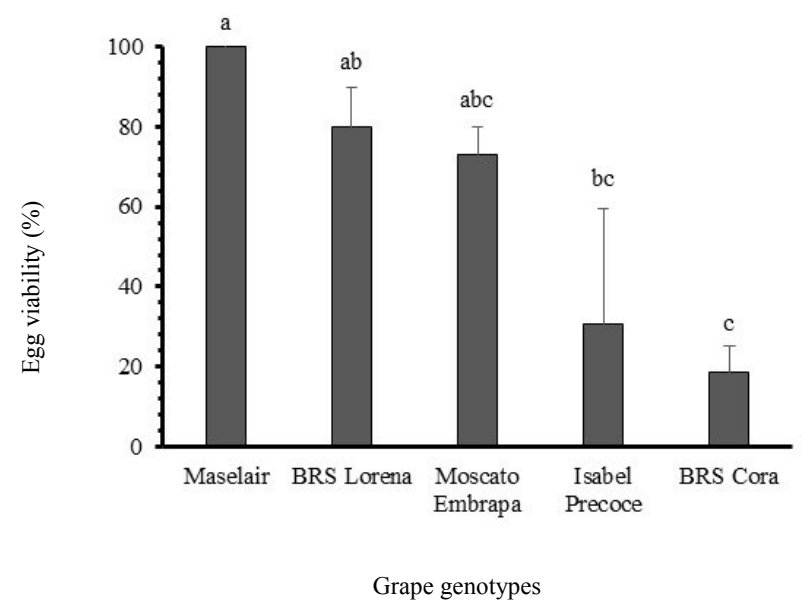

Figure 2. Viability of Ceratitis capitata eggs (Wied.) (Diptera: Tephritidae) in grape berries under laboratory conditions $\left(25 \pm 2^{\circ} \mathrm{C}, 60 \pm 10 \% \mathrm{RH}\right.$ and 14-hour photophase). Means followed by the same letter do not differ by Duncan's test at $5 \%$ probability. 
According to Vera et al. (2014) the pH also influenced egg viability of $A$. fraterculus, which was lower at a $\mathrm{pH}$ of $3.5(16 \%$ to $31 \%)$, and higher at a $\mathrm{pH}$ of 4.0 and $4.5(42 \%$ to $59 \%)$. However, in the present work $A$. fraterculus, even at low $\mathrm{pH}$ conditions (below 3.5) had a high egg viability (above 44\%). According to Papachristos, Papadopoulos and Nanos (2008), $\mathrm{pH}$ values below 4.0 are considered ideal for the development of $C$. capitata. Although all genotypes tested for $C$. capitata had $\mathrm{pH}$ values between 3.1 and 3.4, egg viability was still low (between $31 \%$ and $19 \%$ for Isabel Precoce and BRS Cora, respectively).

Egg viability of $A$. fraterculus was observed in all grape genotypes, although the complete development from egg to adult was not observed in any of the grape genotypes tested (Cabernet Sauvignon, Niágara Rosada, BRS Linda, BRS
Lorena, BRS Cora, Moscato Embrapa, and Maselair). Some previously published papers reported the development of this fruit fly species in the Moscato Embrapa and Itália ( $V$. vinifera) genotypes, both of which have a white exocarp color at the full maturation stage (ZART; FERNANDES; BOTTON, 2010; ZART; BOTTON; FERNANDES, 2011). Furthermore, these same authors observed the oviposition of $A$. fraterculus in the genotypes Niagara Rosada, Cabernet Sauvignon, and Isabel Precoce, but they did not detect the development of larvae, corroborating the results found in the present study.

C. capitata only completed post-embryonic development in the Moscato Embrapa genotype. There was no post-embryonic development in the Isabel Precoce, BRS Lorena, BRS Cora and Maselair genotypes (Table 3).

Table 3. Biological parameters of the Mediterranean fruit fly Ceratitis capitata (Wied.) (Diptera: Tephritidae) in grapes of the Moscato Embrapa grape genotype (Vitis vinifera) under laboratory conditions $\left(25 \pm 2^{\circ} \mathrm{C}, 60 \pm 10 \% \mathrm{RH}\right.$ and 14 -hour photophase).

\begin{tabular}{llll}
\hline Biological parameters & $\mathrm{n}^{1}$ & Mean $\pm \mathrm{SE}^{2}$ & Variation interval \\
\hline Egg-larva period (days) & 41 & $18.8 \pm 1.49$ & $15-27$ \\
Pupa period (days) & 18 & $10.6 \pm 0.22$ & $9-13$ \\
Pupa Viability (\%) & - & $50.0 \pm 10.00$ & - \\
Egg-adult period (days) & 18 & $30.9 \pm 0.95$ & $25-36$ \\
Sex ratio & 18 & $0.51 \pm 0.14$ & $0.25-1$ \\
Pre-oviposition period (days) & 7 & $9.6 \pm 2.08$ & $0-16$ \\
Oviposition period (days) & 7 & $23.9 \pm 8.63$ & $0-57$ \\
Post-oviposition period (days) & 7 & $2.0 \pm 0.65$ & $0-4$ \\
Number of eggs per female & 7 & $50.3 \pm 15.82$ & $0-97$ \\
Male longevity (days) & 7 & $37.0 \pm 16.00$ & $3-109$ \\
Female longevity (days) & 7 & $41.1 \pm 8.92$ & $12-78$ \\
\hline${ }^{1}$ Number of insects observed & & & \\
${ }^{2}$ Mean \pm Standard error & & &
\end{tabular}

The period from egg to larva, pupa and egg to adult of $C$. capitata in grape berries of the Moscato Embrapa genotype lasted 18.8, 10.6, and 30.9 days respectively, which is similar to the results found by Zanardi et al. (2011) in grapes of the Itália genotype (18.2, 11.0, and 32.6 days respectively). According to Gómez et al. (2008) the duration of the period from egg to adult for C. capitata was 29.8 and 27.4 days in the Benitaka and Festival grape genotypes, respectively.

There was no difference between the longevity of females and males of $C$. capitata in the Moscato Embrapa genotype, which was 41.1 and 37.0 days respectively $\left(\chi^{2}=0.0028\right.$, DF $=1$, $P=0.9580)$. When the flies were $35-36$ days old, female survival rate was $50 \%$, and $67 \%$ of the eggs were already oviposited (Figure 3).

The total fecundity of $C$. capitata in the Moscato Embrapa genotype was 50.3 eggs per female, which is lower than the values observed in other studies. The total fecundity of $C$. capitata from post-embryonic development in berries of the Benitaka and the Festival genotypes were 200 and 153 eggs respectively (GÓMEZ et al., 2008). According to Zanardi et al. (2011), the fertility of the Mediterranean fruit fly in the Itália genotype was 216.8 eggs per female, which is lower than the value observed in flies on, for example, peach fruits (434.5 eggs per female).

The evaluation of egg viability in the nochoice test for oviposition showed that the nondevelopment of these species of fruit flies occurred mainly due to the high mortality in the postembryonic stage. This fact may indicate the presence of defensive substances or poor nutritional quality of the host, especially in blue grape berries. According to Comarella et al. (2012), the blue grape genotypes contain a higher quantity of phenolic compounds, such as anthocyanins, than green peel genotypes. 


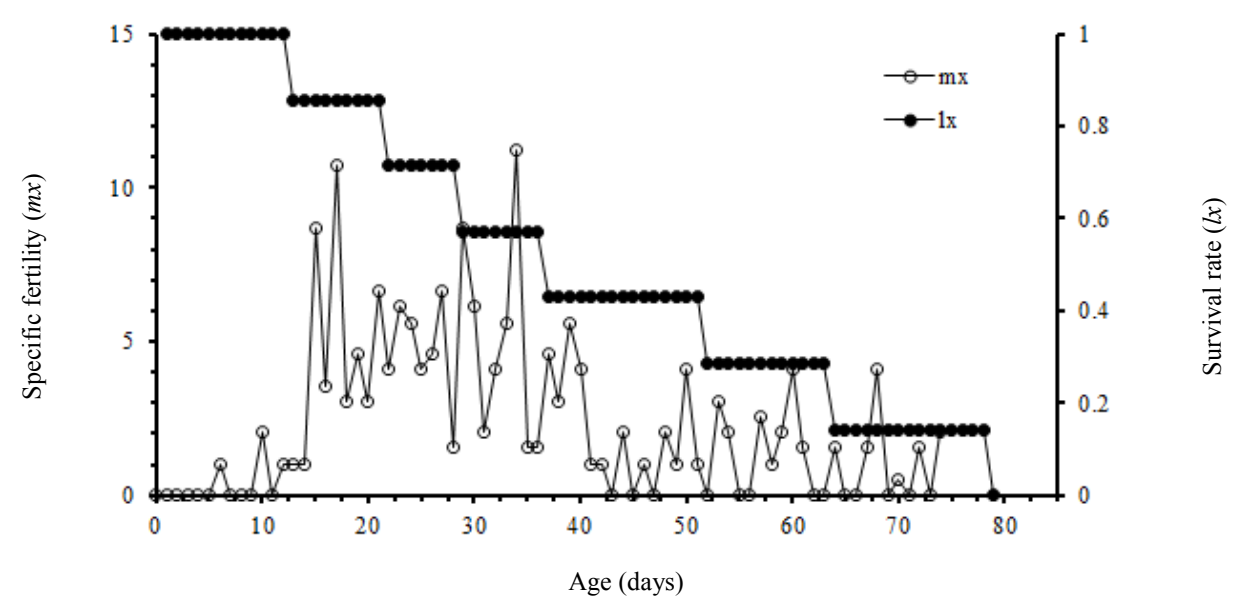

Figure 3. Specific fertility $(\mathrm{mx})$ and female survival rate $(\mathrm{lx})$ of the Mediterranean fruit fly Ceratitis capitata (Wied.) (Diptera: Tephritidae) from the post-embryonic development in grapes of the Moscato Embrapa grape genotype (Vitis vinifera) under laboratory conditions $\left(25 \pm 2^{\circ} \mathrm{C}, 60 \pm 10 \% \mathrm{RH}\right.$ and 14-hour photophase).

Baker (1945) observed oviposition hosts of a Mexican A. fraterculus population, and reported that grapes were the most preferred fruit for oviposition, compared to guava, loquat, and peach, although the insects were not able to complete their larval stage in grapes. Thus, the results suggest that there are hosts that are more favorable for fruit fly reproduction than grapes, indicating that this fruit is a secondary host for A. fraterculus and C. capitata.

Similar results were also found for other species of fruit flies. As observed by Andreazza et al. (2016), grapes were not considered a suitable host for the development of the spotted-wing drosophila, Drosophila suzukii (Matsumura) (Diptera: Drosophilidae), which was recently identified in Brazil. The oviposition was between 0.2 and 4.6 eggs per grape in genotypes which were considered susceptible, but adult emergence did not exceed $5.7 \%$. There was no oviposition in the genotypes which were considered resistant, among them, the Itália, Isabel and Niagara Rosada genotypes.

Although grapes may be considered a secondary host for fruit flies, in the present work, all genotypes were considered to be susceptible to $A$. fraterculus and $C$. capitata. This is due to the fact that these insect species can compromise the quality of the grapes by indirectly damaging fruit berries due to fungal infections in the pre-harvest stage (ENGELBRECHT; HOLZ; PRINGLE, 2004; RODITAKIS; TSAGKARAKOU; RODITAKIS, 2008; MACHOTA JÚNIOR et al., 2013).

Field conditions demonstrated that the mechanical action of the A. fraterculus ovipositor increased the penetration of Botrytis cinerea, Glomerella cingulata and microorganisms which cause sour rot in the Itália grape genotype. Thus, for the right management of fruit flies, the use of integrated pest and disease management programs is recommended (MACHOTA JÚNIOR et al., 2016). Furthermore, field experiments need to be done in order to better evaluate the preference of fruit fly oviposition in different grape genotypes, and to link this to the epidemiology of fungal diseases in grape berries.

\section{CONCLUSIONS}

The genotypes Cabernet Sauvignon, Niagara Rosada, and BRS Cora were the most preferred for A. fraterculus oviposition. However, the development of $A$. fraterculus larvae was not observed in any of the genotypes evaluated (Cabernet Sauvignon, Niagara Rosada, BRS Linda, BRS Lorena, BRS Cora, Moscato Embrapa and Maselair). The Isabel Precoce genotype was the most preferred for $C$. capitata oviposition. Grape berries of the Moscato Embrapa genotype were the only ones that allowed the development of larvae and pupae of C. capitata.

\section{ACKNOWLEDGEMENT}

We would like to thank FUMDES for granting the master's degree to the first author, and FAPESC for the financial support during this study (CP 06/2013 TO 2013 TR 3395). We would like to thank the Fruticulture laboratory of the Santa Catarina State University (UDESC / CAV) for supplying the grape genotypes used in the assays. We further thank the researcher Dr. Marcos Botton (EMBRAPA / Uva e Vinho) for suggestions on how to write this paper.

\section{REFERENCES}

ANDREAZZA, F. et al. Suscetibilidade de bagas de genótipos de videira pela infestação por Drosophila 
suzukii (Diptera: Drosophilidae). Pesquisa Agropecuária Brasileira, Brasília, v. 51, n. 5, p. 599-606, 2016.

BAKER, E. W. Studies on the Mexican fruit fly known as Anastrepha fraterculus. Journal of Economic Entomology, Lanham, v. 38, n. 1, p. 95100, 1945.

COMARELLA, C. G. et al. Polifenóis totais e avaliação sensorial de suco de uvas Isabel tratadas com ultrassom. Brazilian Journal of Food Technology, Campinas, Ed. Especial, IV Simpósio de Segurança Alimentar, IV SSA, p. 69-73, 2012.

DÍAZ-FLEISCHER, F; ALUJA, M. Clutch size in frugivorous insects as a function of host firmness: the case of the tephritid fly Anastrepha ludens. Ecological Entomology, Medford, v. 28, n. 3, p. 268 $-277,2003$.

ENGELBRECHT, R.; HOLZ, G.; PRINGLE, K. L. Occurrence of fruit-decaying fungi on adult male Mediterranean fruit flies (Ceratitis capitata) captured in orchards and adjacent vineyards. South African Journal of Enology and Viticulture, Dennesig, v. 25, n. 2, p. 48-53, 2004.

FACHINELLO, J. C. et al. Situação e perspectivas da fruticultura de clima temperado no Brasil. Revista Brasileira de Fruticultura, Jaboticabal, v. 33, Sup., p. 109-120. 2011.

FORMOLO, R. et al. Diagnóstico da área cultivada com uva fina de mesa (Vitis vinifera L.) sob cobertura plástica e do manejo de pragas. Revista Brasileira de Fruticultura, Jaboticabal, v. 33, n. 1, p. 103-110, 2011.

GARCIA, F. R. M.; CORSEUIL, E. Flutuação populacional de Anastrepha fraterculus (Wiedemann) e Ceratitis capitata (Wiedemann) (Diptera: Tephritidae) em pomares de pessegueiro em Porto Alegre, Rio Grande do Sul. Revista Brasileira de Zoologia, Curitiba, v. 15, n. 1, p. 153158, 1998.

GARCIA, F. R. M.; NORRBOM, A. L. Tephritoid flies (Diptera, Tephritoidea) and their plant hosts from the State of Santa Catarina in Southern Brazil. Florida Entomologist, Lutz, v. 94, n. 2, p. 151-157, 2011.

GÓMEZ, M. et al. Biología de la mosca del mediterrâneo, Ceratitis capitata Wiedemann (Díptera: Tephritidae) em dos genótipos de uva de mesa (Vitis vinífera L.) en el nordeste Brasileño. Revista CitriFrut, Havana, v. 25, n. 2, p. 18-23, 2008.
LORSCHEITER, R. et al. Caracterização de danos causados por Anastrepha fraterculus (Wiedemann) (Diptera, Tephritidae) e desenvolvimento larval em frutos de duas cultivares de quivizeiro (Actinidia spp.). Revista Brasileira de Fruticultura, Jaboticabal, v. 34, n. 1, p. 67-76, 2012.

MACHOTA JÚNIOR, R. et al. Assessment of injuries caused by Anastrepha fraterculus (Wied.) (Diptera: Tephritidae) on the incidence of bunch rot diseases in table grape. Neotropical Entomology, Londrina, v. 45, n. 4, p. 361-368, 2016.

MACHOTA JÚNIOR, R. et al. Fungi that cause rot in bunches of grape identified in adult fruit flies (Anastrepha fraterculus) (Diptera: Tephritidae). Chilean Journal of Agricultural Research, Chillán, v. 73, n. 2, p. 196-201, 2013.

MACHOTA JÚNIOR, R. et al. Técnica de criação de Anastrepha fraterculus (Wied. 1830) (Diptera: Tephritidae) em laboratório utilizando hospedeiro natural. Bento Gonçalves: Embrapa Uva e Vinho, 2010. 23 p. (Boletim de Pesquisa e Desenvolvimento, 15).

MELLO, L. M. R. Panorama da produção de uvas e vinhos no Brasil. Campo \& Negócios Hortifruti, Uberlândia, v. 12, n. 142, p. 54-56, 2017.

MORELLI, R. et al. New protein sources in adults diet for mass-rearing of Anastrepha fraterculus (Diptera: Tephritidae). Brazilian Archives of Biology and Technology, Curitiba, v. 55, n. 6, p. 827-833, 2012.

MUHAMMAD, D. G. et al. Bio-physical bases of antixenotic mechanism of resistance in bitter-gourd (Momordica charantia 1., cucurbitacae) against melon fruit fly, Bactrocera cucurbitae (Coquillett) (Diptera: Tephritidae). Pakistan Journal of Botany, Karachi, v. 42, n. 2, p. 1251-1266, 2010.

NAVA, D. E. et al. Mosca em surto. Cultivar Hortaliças e Frutas, Pelotas, v. 8, n. 52, p. 26-29, 2008.

NUNES, M. Z. et al. Damage and development of Anastrepha fraterculus (Diptera: Tephritidae) in fruits of two pear cultivars. Agrociencia Uruguay, Montevideo, v. 19, n. 2, p. 42-48, 2015.

PAPACHRISTOS, D. P.; PAPADOPOULOS, N. T. NANOS, G. D. Survival and development of immature stages of the Mediterranean fruit fly (Diptera: Tephritidae) in citrus fruit. Journal of Economic Entomology, Oxford, v. 101, n. 3, p. 866 $-872,2008$.

PROTAS, J. F. S.; CAMARGO, U. A. 
Vitivinicultura Brasileira: panorama setorial de 2010. 1. ed. Brasília, DF: SEBRAE, 2011. 110 p.

RIBEREAU-GAYON, P. et al. Traité d'oenologie: chimie du vin: stabilisiation et traitements. Paris: Dumond, 1998. 519 p.

RODITAKIS, E.; TSAGKARAKOU A.; RODITAKIS, N. E. Extensive damage on white variety table grapes by the Mediterranean fruit fly (Ceratitis capitata Wiedemann) in Crete. Bulletin OEPP/EPPO Bulletin, Paris, v. 38, n. 2, p. 216$219,2008$.

SALLES, L. A. B. Metodologia de criação de Anastrepha fraterculus (Wied., 1830) (Diptera: Tephritidae) em dieta artificial em laboratório. Anais da Sociedade Entomológica do Brasil, Viçosa, v. 21, n. 3, p. 479-486, 1992.

SAS INSTITUTE. SAS User's guide: statistics. Software Version 9.0. Cary, NC, USA, 2002.

SILVEIRA NETO, S. et al. Manual de Ecologia dos Insetos. Piracicaba, SP: Ceres, 1976. 419 p.

TERAN, H. R. Comportamiento alimentario y su correlacion a la reproduccion em hembras de Ceratitis capitat (Wied.) (Diptera: Trypetidae). Revista Agronómica del Noroeste Argentino, Tucumán, v. 14, n. 1-4, p. 18-34, 1977.

VERA, M. T. et al. Development of a larval diet for the South American fruit fly Anastrepha fraterculus (Diptera: Tephritidae). International Journal of Tropical Insect Science, Nairobi, v. 34, Sup., p. S73 -S81, 2014.

ZANARDI, O. Z. et al. Desenvolvimento e reprodução da mosca-do-mediterrâneo em caquizeiro, macieira, pessegueiro e videira. Pesquisa Agropecuária Brasileira, Brasília, v. 46, n. 7, p. 682-688, 2011.

ZART, M.; BOTTON, M.; FERNANDES, O. A. Injúrias causadas por mosca-da-fruta sul-americana em genótipos de videira. Bragantia, Campinas, v. 70, n. 1, p. 64-71, 2011.

ZART, M.; FERNANDES, O. A.; BOTTON, M. Biology and fertility life table of the South American fruit fly Anastrepha fraterculus on grape. Bulletin of Insectology, Bologna, v. 63, n. 2, p. 237-242, 2010. 